\title{
Pemodelan dan Validasi Nilai Sudut Antihan Benang Secara Teori dan Pengolahan Citra Digital
}

\author{
Wilda Murti ${ }^{1, *}$, Andrian Wijayono ${ }^{1}$, Valentinus Galih Vidia Putra ${ }^{2}$ and Wiah Wardiningsih ${ }^{3}$ \\ 1 Politeknik STTT Bandung, Textile Engineering, Jl. Jakarta no.31, Bandung, Indonesia; \\ wilda.murti@gmail.com. \\ 2 Politeknik STTT Bandung, Head of Physics Laboratory, Jl. Jakarta no.31, Bandung, Indonesia; \\ valentinus@kemenperin.go.id. \\ 3 Politeknik STTT Bandung, Head of Textile Evaluation Laboratory, Jl. Jakarta no.31, Bandung, Indonesia; \\ wiahwards@gmail.com. \\ * Correspondence: wilda.murti@gmail.com; Tel.: +62-8180-9980-810
}

Intisari: Penelitian ini bertujuan untuk membandingkan hasil pengukuran sudut guna mengukur besarnya antihan benang secara teori dan pengolah citra. Hubungan antara variabel sudut antihan benang dan antihan benang secara teoritis dirumuskan sebagai . Perbandingan hasil pengukuran sudut antihan benang secara eksperimen dari beberapa sampel benang telah didapatkan. Telah ditemukan bahwa nilai sudut antihan benang secara eksperimen dan teori pemodelan memiliki nilai yang relatif sama (tidak bebeda secara signifikan) melalui analisis uji T-test pada signifikansi 0,95.

Kata Kunci: sudut antihan benang, antihan benang, pengolah citra.

\section{Pendahuluan}

Sudut antihan merupakan salah satu elemen yang penting ketika mendiskusikan antihan pada benang. Sudut antihan terbentuk karena serat-serat yang dipintal menjadi benang diberikan antihan atau twist agar serat-serat tersebut saling berikatan sehingga memiliki kekuatan yang cukup untuk menjadi benang. Menurut Lawrence (2003) sudut antihan dan arah antihan benang merupakan faktor yang mempengaruhi bentuk kenampakan pada benang seperti terlihat pada Gambar 1, $r$ adalah jejari benang, $\alpha$ adalah sudut antihan dan $h$ adalah tinggi atau panjang benang.

Lawrence (2003) mengemukakan bahwa sudut antihan merupakan salah satu dari 4 faktor penting dari antihan pada benang. Empat faktor penting dari antihan yang dikemukakan Lawrence (2003) adalah sudut antihan, arah antihan, twist level dan twist multiple. Sudut antihan berperan penting untuk ketiga faktor lainnya.

Nilai sudut antihan () pada benang memiliki hubungan atau korelasi yang erat dengan twist level atau degree of twist yaitu banyaknya puntiran pada benang per satuan panjang tertentu, seperti turns per inch (tpi) atau dalam satuan metrik yaitu turns per meter (tpm) dan turns per centimeter (tpcm), yang mengacu pada rumusan Lawrence (2003) yaitu sehingga berdasarkan persamaan tersebut, sudut antihan benang () dapat dihitung dengan mengetahui diameter dan antihan pada suatu benang. 


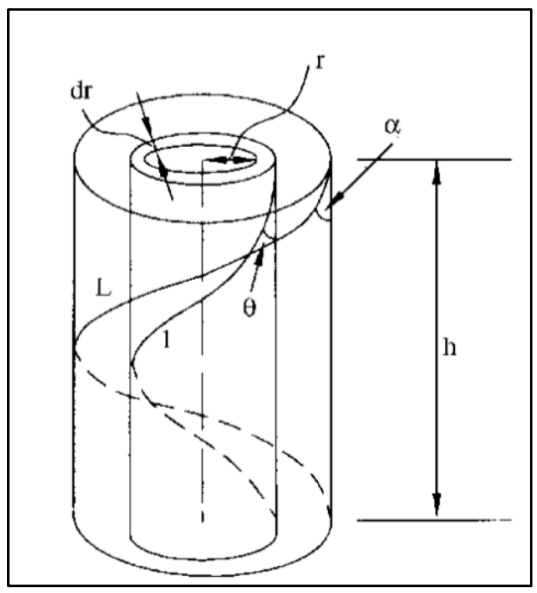

Gambar 1. Pemodelan bentuk helix pada benang (Lawrence, 2003)

Salah satu cara lain untuk menentukan sudut antihan benang (secara eksperimen) adalah dengan menggunakan teknologi pengolah citra digital. Lazlo, dkk (1994) mengatakan bahwa dengan menggunakan alat konvensional akan sedikit sulit untuk menentukan sudut antihan pada benang, akan tetapi jika dibantu dengan teknologi pengolah citra, besarnya nilai sudut antihan akan lebih mudah diukur dan waktu yang dibutuhkan untuk melakukan pengujian akan lebih cepat. Penentuan sudut tersebut dapat dilakukan dengan menganalisis citra digital dari benang yang diamati, kemudian analisis dapat dilakukan dengan menggunakan perangkat lunak pengolah citra digital, sehingga dihasilkan hasil pengukuran dalam bentuk sudut.

Sudut antihan adalah penting untuk diketahui nilainya. Lawrence (2003) telah menyatakan hubungan antara sudut antihan dengan diameter dan twist level, maka dimungkinkan untuk mendapatkan suatu nilai prediksi diameter atau nilai twist level pada benang tersebut.

Pada penelitian ini telah digunakan empat jenis benang ring spinning (dengan nilai antihan yang berbeda) berbahan poliester telah digunakan pada proses validasi eksperimen. Penelitian ini bertujuan untuk membandingkan nilai sudut antihan benang dari hasil pengukuran sudut antihan benang menggunakan pengolah citra dengan hasil prediksi pemodelan sudut antihan benang pada koordinat silinder

\section{Pemodelan Sudut Antihan Benang}

Menurut Putra (2017), dapat dimodelkan sudut antihan secara teori pada koordinat silinder sebagai berikut:

$$
\begin{gathered}
d s^{2}=g_{m n} d x^{m} d x^{n}=\left(d s^{2}+d y^{2}+d z^{2}\right)=\left(d \rho^{2}+\rho^{2} d \varphi^{2}+d z^{2}\right) \\
\mathrm{g}_{m n}=\left(\begin{array}{ccc}
\mathrm{g}_{11} & 0 & 0 \\
0 & \mathrm{~g}_{22} & 0 \\
0 & 0 & \mathrm{~g}_{3}
\end{array}\right)=\left(\begin{array}{ccc}
1 & 0 & 0 \\
0 & \rho^{2} & 0 \\
0 & 0 & 1
\end{array}\right) \\
\frac{d^{2} x^{\eta}}{d t^{2}}+\Gamma_{\alpha \beta}^{\eta} \frac{d x^{\alpha}}{d t} \frac{d x^{\beta}}{d t}=A^{\eta}=0
\end{gathered}
$$

Dengan menggunakan simbol cristoffel, didapatkan persamaan berikut:

$$
\begin{gathered}
\frac{d^{2} \varphi}{d t^{2}}+\frac{2}{\rho} \dot{\varphi} \dot{\rho}=A^{\varphi}=0, \\
\frac{d z}{d t}=\dot{z}=\text { const } \\
\left(\frac{d l}{d z}\right)^{2}=1+\left(\frac{d \rho}{d z}\right)^{2}+\left(\rho \frac{d \varphi}{d z}\right)^{2} .
\end{gathered}
$$




$$
\begin{gathered}
\left(\frac{d l}{d z}\right)^{2}=1+m_{\text {serat }}{ }^{2}+(\tan \propto)^{2} . \\
(\sec \theta)^{2}=1+m_{\text {serat }}{ }^{2}+(\tan \propto)^{2} . \\
\tan ^{2} \theta=m_{\text {serat }}{ }^{2}+\tan ^{2} \alpha . \\
\tan ^{2} \theta-\tan ^{2} \alpha=m_{\text {serat }}{ }^{2} .
\end{gathered}
$$

Dari persamaan (10), jika nilai migrasi serat bernilai nol untuk satu putaran penuh, sehingga:

$$
\begin{gathered}
\sqrt{\tan ^{2} \theta-\tan ^{2} \alpha}=m_{\text {serat }}^{2}=0 . \\
\tan \theta=\tan \propto . \\
\tan \theta=2 \pi r T
\end{gathered}
$$

dimana merupakan sudut antihan pada benang, adalah jejari benang dan adalah antihan benang. Rumusan tersebut sesuai dengan rumusan sudut antihan yang ditunjukan oleh Lawrence (2003), yaitu:

$$
T=\frac{\tan \theta}{2 \pi r}
$$

Berdasarkan rumusan tersebut, nilai sudut antihan pada benang akan mempengaruhi diameter benang dan antihan pada benang. Untuk nilai diameter benang konstan, semakin besar nilai, maka akan semakin besar pula antihan benang tersebut. Untuk antihan yang sama, semakin besar nilai, maka akan semakin besar pula diameter benangnya.

\section{Validasi Eksperimen}

Validasi eksperimen pada penelitian ini dilakukan untuk membuktikan nilai sudut antihan benang dari hasil pemodelan terhadap nilai sudut antihan secara eksperimen. Pada penelitian ini telah didapatkan hasil pengukuran diameter benang, antihan benang, sudut antihan secara teori dan sudut antihan secara eksperimen pada empat jenis benang sampel berbahan poliester dari mesin ring spinning seperti tercantum pada Tabel 1.

Pengukuran diameter benang dan sudut antihan benang eksperimen telah dilakukan dengan menggunakan alat yarn diameter and twist angle tester device. Pada penelitian ini, analisis image processing telah dilakukan dengan menggunakan perangkat lunak pengolah citra digital dengan metode seleksi daerah. Perangkat lunak tersebut dapat menganalisis citra digital serta menghasilkan hasil pengukuran

\begin{tabular}{|c|c|c|c|c|c|}
\hline No & $\begin{array}{l}\text { Jenis sampel } \\
\text { benang }\end{array}$ & $\begin{array}{c}\text { Diameter } \\
\text { benang (inch) }{ }^{1}\end{array}$ & $\begin{array}{c}\text { Antihan Benang } \\
\text { (TPI) }^{2}\end{array}$ & $\begin{array}{l}\text { Sudut antihan } \\
\text { secara teori }\left({ }^{\circ}\right)^{3}\end{array}$ & $\begin{array}{l}\text { Sudut antihan secara } \\
\text { eksperimen }\left(^{\circ}\right)^{4}\end{array}$ \\
\hline 1 & $\begin{array}{l}\text { Benang polyester } \\
\text { ring spinning } \mathrm{Ne}_{1} 40\end{array}$ & $0,0059 \pm 0,0001$ & $20,1981 \pm 0,5725$ & $20,7954 \pm 0,7799$ & $20,8435 \pm 0,3508$ \\
\hline 2 & $\begin{array}{l}\text { Benang polyester } \\
\text { ring spinning } \mathrm{Ne}_{1} 30\end{array}$ & $0,0065 \pm 0,0003$ & $17,7 \pm 0,4647$ & $20,0164 \pm 1,0123$ & $20,049 \pm 0,6925$ \\
\hline 3 & $\begin{array}{l}\text { Benang polyester } \\
\text { ring spinning } \mathrm{Ne}_{1} 20\end{array}$ & $0,0083 \pm 0,0004$ & $14,3984 \pm 0,3162$ & $20,6505 \pm 1,1117$ & $20,2979 \pm 0,3719$ \\
\hline 4 & $\begin{array}{l}\text { Benang polyester } \\
\text { ring spinning Ne1 } 10\end{array}$ & $0,0121 \pm 0,0002$ & $12,6052 \pm 0,3199$ & $25,7283 \pm 0,6027$ & $24,6275 \pm 0,8901$ \\
\hline
\end{tabular}
diameter benang dan sudut antihan benang dalam satuan milimeter. Pengukuran yang telah dilakukan termasuk pada sistem visual. Pengukuran dilakukan dengan cara menganalisis citra digital pandangan benang yang ditangkap dengan menggunakan suatu perangkat mikroskop digital dan menggunakan teknik analisis image processing. Perangkat mikroskop yang telah digunakan untuk mengukur diameter benang yaitu perangkat mikroskop digital endoskop berkapasitas pembesaran 500x dengan ketajaman 1200 x 900 pixel.

Tabel 1. Hasil validasi eksperimen sudut antihan benang 
1Diameter benang diukur dengan menggunakan metoda pengolah citra digital menggunakan perangkat yarn yarn diameter and twist angle tester device.

${ }^{2}$ Antihan benang diuji dengan alat pengukur antihan benang metoda twist-untwist dengan metode yang sesuai dengan SNI ISO 17202:2010 (Tekstil - Cara uji antihan benang pintal tunggal - Metoda pembukaan dan pemberian antihan).

${ }^{3}$ Nilai sudut antihan benang teori dihitung dengan menggunakan persamaan Lawrence (2003).

${ }^{4}$ Nilai sudut antihan benang eksperimen diukur dengan menggunakan metoda pengolah citra digital menggunakan perangkat yarn diameter and twist angle tester device.

Dengan mengetahui diameter benang dari hasil pengujian nomor benang pada setiap sampel uji, serta mengetahui antihan benang dari hasil pengujian antihan benang, dapat diketahui nilai sudut antihan benang teoritis berdasarkan persamaan (14). Nilai sudut antihan benang dari hasil validasi eksperimen dapat dilihat pada Tabel 1. Grafik perbandingan nilai sudut antihan benang secara eksperimen dan pemodelan teoritis dapat dilihat pada Gambar 2.

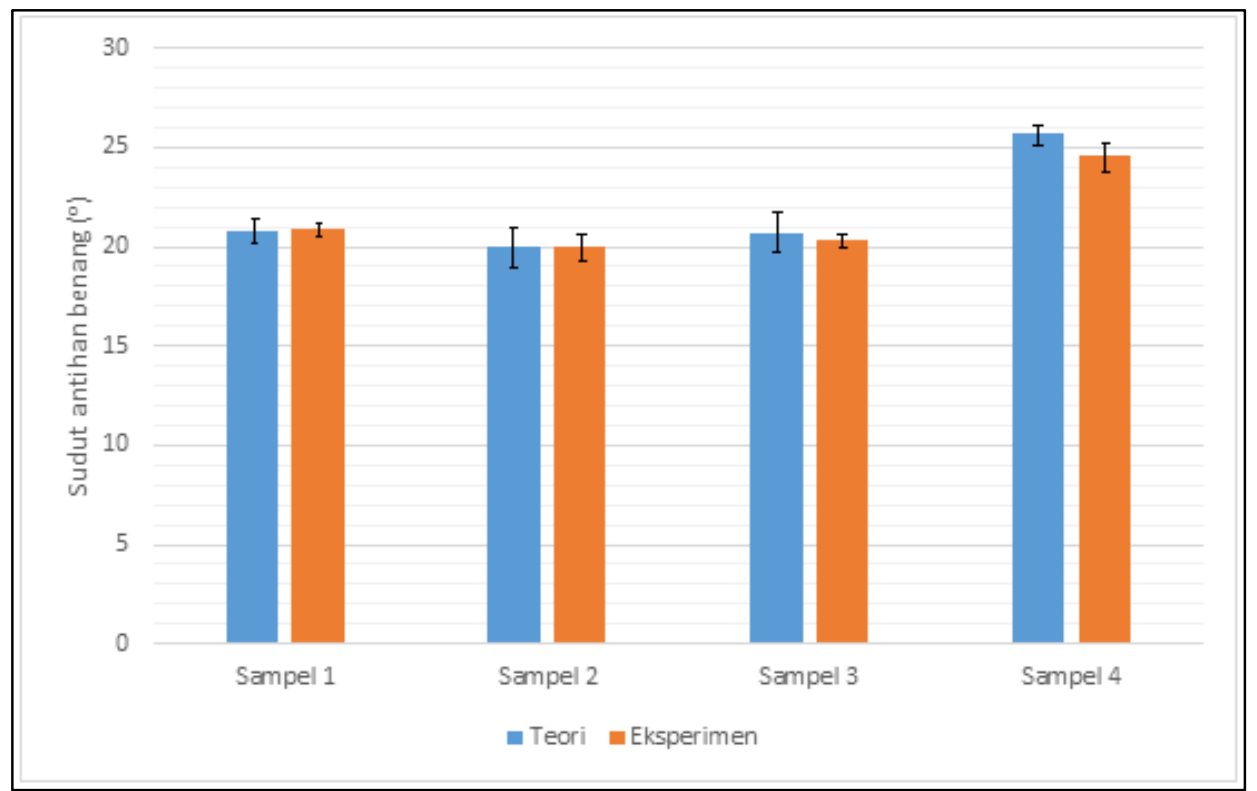

Gambar 2. Perbandingan nilai sudut antihan benang secara ekperimen dan pemodelan teoritis

\section{Hasil dan Pembahasan}

Dari hasil validasi eksperimen nilai sudut antihan benang, dapat dilihat bahwa hasil validasi sudut antihan benang secara eksperimen dan secara pemodelan tidak memberikan nilai yang berbeda secara signifikan (dapat dilihat pada grafik Gambar 2). Telah dilakukan analisis uji $\mathrm{T}$ test signifikansi 0,95 pada data hasil validasi tersebut untuk melihat kesamaan rata-rata dari hasil nilai sudut antihan secara validasi dan ilai sudut antihan secara teori. Berdasarkan hasil analisis tersebut, didapatkan kesimpulan data tidak berbeda secara signifikan pada tingkat confidence level 0,95. Dengan demikian dapat dikatakan bahwa pemodelan antihan benang tersebut telah dapat memprediksi sudut antihan benang.

\section{Kesimpulan}

Pada penelitian ini telah didapatkan bahwa rumusan sudut antihan benang menggunakan pemodelan benang pada koordinat silinder adalah, dengan hubungan antara sudut antihan benang dengan antihan benang adalah berbanding lurus untuk nilai diameter yang konstan (semakin besar sudut antihan benang, maka akan semakin besar antihan benang). Berdasarkan hasil validasi eksperimen, didapatkan kesimpulan nilai sudut antihan benang yang tidak berbeda secara signifikan pada tingkat confidence level 0,95 dengan menggunakan uji T-test. Dengan demikian dapat dikatakan bahwa pemodelan antihan benang tersebut telah dapat memprediksi sudut antihan benang. 
Author Contributions: Wilda Murti designed, performed validation of experiment and wrote the paper; Andrian Wijayono performed the statistical analysis from the experimental result; Valentimus Galih Vidia Putra designed the yarn diameter modelling; and Wiah Wardiningsih conceived and designed the experiments.

\section{References}

1. Lawrence, 2010, Advances in Yarn Spinning Technology, Woodhead Publishing, Cambridge.

2. Lazlo, dkk., 1994, Measurement of Yarn Diameter and Twist Angle With Image processing, Periodica Polytechnica ser. mech. eng. vol. 38, No. 4, hal 277-296.

3. Putra, VGV, 2017, Pemodelan Analisa Struktur dan Mekanis Serat Benang Open End Spinning Dalam Rangka Menentukan Sudut Puntiran (Kajian Teoritik), Universitas Gadjah Mada, Yogyakarta.

4. SNI ISO 17202:2010, Tekstil-Cara Uji Antihan Benang Tunggal Sistem Pembukaan dan Pemberian Antihan, Badan Standarisasi Nasional. 